\title{
MANAGING OF THE 2008 FINANCIAL CRISIS BY THE GOVERNMENT OF THE REPUBLIC OF MACEDONIA AND ITS IMPACT ON THE BUSINESS SECTOR
}

\author{
JETON MAZLLAMI
}

https://doi.org/10.35945/gb.2017.03.006

Assistant professor of SEEU Tetovo, Macedonia

\author{
IZET ZEQIRI \\ Full professor of SEEU Tetovo, Macedonia
}

\author{
BRIKEND AZIRI
}

Associate professor of STU Tetovo, Macedonia

\section{KEYWORDS: ANTI CRISIS MEASURES, SME'S, INVESTMENTS, EMPLOYMENT ACT}

\section{INTRUDUCTION}

The global financial crisis of the first decade of this century deserves special attention and treatment as one of the most important economic events since the oil crisis of the 70s. The global financial crisis gave a severe blow to the world economy development in general. The negative effects of the global financial crisis began to feel mostly in 2008. Almost all the national economies, including the Macedonian economy, were faced with the challenges of financial instability. Due to the created situation the government introduced a wide range of anti-crisis measures with the aim of insuring financial stability in the country. But, in the case of the Republic of Macedonia, until now there is a gap in research, regarding the consequences of the global financial crisis on business in general and small and medium sized enterprises in particular. Although this paper summarizes the main macroeconomic effects of the global financial crisis on the Macedonia economy, still it is more focused on the effects of the global financial crisis on SME's. In fact this paper is based on a large scale research of SME's in the Pollog region, being one of the biggest and most specific regions in the country, but from the point of view of capital owners.

A number of analysts, as the official starting date of the global financial crisis consider-9 August 2007, the date of the disorders seen in the interbank market in the relation American-European markets. In fact, after a long period of interest rate stability of the national banks of European countries on average 4\%, on August 9, 2007 came to its growth in $4.4 \%$. This led to the appearance of the impression that banks have no willingness to lend to each other and this is the result of their lack of liquidity. The same situation occurred in European money markets, both in the U.S. For this reason, the same day, European Central Bank intervened with the release of an amount of 95 billion Euros to increase the liquidity of the market, while U.S. Federal Reserve's also intervened with an amount of 24 billion dollars. However, such interventions which were repeated many times in the coming months could not affect the stabilisation of the markets.
The economy of the R.M. did not have the necessary immunity to face the worldwide "virus" created by the Global financial crisis. In order to prevent and alleviate the negative consequences from this virus, the government of the RM in 2008 and 2009 has implemented anti-crisis package of measures. The main purpose of this paper is to provide an analysis of the impact of the global financial crisis on SME's in the Pollog region, rather than providing an extensive review of global financial crisis and their impact on the world economy in general.

\section{LITERATURE REVIEW}

The financial crisis shall mean a stated range of threats to stability, security and functionality of the financial system in a national economy. Financial crisis is usually developed, followed or accompanied by a collapse in prices of securities, even though in the absence of financial crisis, an overall drastical decrease of the prices was also marked. The financial crisis usually means a panic in which depositors and lenders tend to withdraw their financial assets from financial institutions and markets, in which case the banks are threatened by insolvency. However, panic may be only one phase of a long period of instability. The financial crisis usually encourages recession, even though many recessions have not been announced by financial crisis. Financial crisis begins with an economic shock and ends with the stabilisation and normalization of the market. (Brunner, Bott, 2009, p. 20)

When it comes to financial crises, we should consider that they have been always caused by a specific occurrence. Such occurrences usually have the following characteristics (Brunner, Bott, 2009, p. 22):

- Wide the occurrence must be so great that can cause a system oscillation

- The rare and unique. In order to cause a change, according to the investors' attitudes, it must necessarily be specific, authentic, and evident that it is not a coincidence.

- Surprising, by definition, in order to be the cause of changes the relevant occurrence must be unpredictable 
and must appear as a surprise for the market players.

The costs of crises are considerable-and taxpayers foot the bill. Indeed, one of the lessons of experience is that the liabilities of the banking system are in fact contingent public debt: the banking industry privatizes its gains and socializes its losses as soon as those losses become large enough to wipe out its equity, and sometimes even before. According to a superb database put together by researchers at the World Bank in 2003, there had been 117 systemic banking crises (in which much or all of the capital of the system was exhausted) in ninety-three countries since the late 1970s. Twenty-seven of these crises imposed fiscal costs equal to or exceeding 10 percent of GDP. In other words, they involved a jump in public debt equal to 10 percent of GDP. Often the cost was much more. The most expensive crises were those in Indonesia after 1997 and in Argentina in the early 1980s, both of which cost taxpayers 55 percent of GDP. (Wolf, 2008, p. 32).

The global financial crisis of the first decade of this century deserves special attention and treatment as one of the most important economic events since the Great Depression of the interwar period, the oil crisis of the 70s.

The financial crisis that is wreaking havoc in financial markets in the U.S. and across the world has its origins in an asset price bubble that interacted with new kinds of financial innovations which masked risk, with companies which failed to follow their own risk management procedures, and with regulators and supervisors who failed to restrain excessive taking. We start by giving the factors that we judge contributed to the bubble in home prices and its interaction with financial markets. We then turn our attention to the issue of increases in capital requirements for financial institutions. Lack of capital, or excess leverage, was only one of the culprits in the disaster; however, raising capital requirements is an important step towards a more stable financial sector (Baily, Elliott, 2011, p.59).

\section{MANAGING THE 2008 FINANCIAL CRISIS BY THE} GOVERNMENT OF THE REPUBLIC OF MACEDONIA

The economy of the R.M. did not have the necessary immunity to face the worldwide "virus" created by the Global financial crisis. In order to prevent and alleviate the negative consequences from this virus, the government of the RM during the period 2008-2010 has implemented some anti-crisis package of measures. From 2008 to 2009, the government has introduced three packages of anti-crisis measures and a fourth one during 2010 (Mazllami, Zeqiri and Aziri, 2011, p.59).

\subsection{The first package of the anti-crisis measures}

The financial crisis was felt profoundly in the half of 2008; therefore the RM government in November 2008 brought the first set of anti-crisis measures. This package included tax re- lief measures: profit tax, tax farmers, reduction of customs and social contributions, etc., which reached the value of 330 million Euros. The purpose of this package was directed towards the real sector, in order to protect the liquidity of the economic subjects that were at risk and the protection of bankruptcy with which many people would lose their jobs.

This package had a superficial and indirect effect by favouring the most evil loaners and not the people who were really affected by the financial crisis.

\subsection{The second package of the anti-crisis measures}

After the implementation of the first package the Macedonian government, in addition, intervened with a second package, bringing 8-year program of realization of infrastructural projects in the amount of EUR 8 billion. This program should include road and railway projects, projects in the energy sector, residential construction and sports, environmental projects etc. The government in this case plans to conclude the financial design of the railway towards Bulgaria as well as the revitalization a part of the hydroelectric power plants in Bitola and the network of high conductors..

The Government of the Republic of Macedonia, through the liberal policy of public investment, government expenditures, wanted to give a stimulus to the development of the economy, but on the other hand, those projects were not inclusive because it was only invested in one part of the territory, and by creating unproductive infrastructure projects (Skopje 2014), did not let us understand that these measures will give a new spirit to the domestic economy in all parts of the territory of RM.

\subsection{The third package of the anti-crisis measures}

The negative effects of financial crisis continued in 2009, where the first quarter marked the deepest recession in the economy of R. of Macedonia, as well as in many countries of the EU and the U.S. The government of RM, considering this situation created, decided to release the third package of anti-crisis measures in April 2009, the most serious package in direction of alleviating the recession deepened in this country. The measures taken by the government in large part were harmonized with the approaches of the business community and economic experts. This package contains the structure included 70 anti-crisis measures in three segments: The budgets rebalance for 2009, Credit support of economic subjects and other measures to support economic entities-companies.

Rebalance of the budget for $\mathbf{2 0 0 9}$ The rebalance of the budget for 2009 would cut the budget for about $9 \%$, by rationalizing expenditures to about 173 million Euros (10.6 billion denars). Through the rebalance, the government wanted to convey the safety message about the possible budget deficit, projected by the level of $2,8 \%$ of GDP by reducing public spending seriously in many areas(high budget deficit poses a 
serious problem in many EU member countries as Greece and Spain). Here we will mention some of the stated measures:

- Temporary interruption of employment (in 2009) in the state administration and public sector (except for employment that are provided by the National Programme for the benefit of the right of EU accession and implementation of the Ohrid FA-ent);

- $\quad 10 \%$ of salary increase in the state in 2010 is delayed (the scheduled November2009);

- Average reduction of about $16 \%$ of current expenditure items of all budget users;

- Reducing the number of trips and number of delegations;

- Reduction of Representation expenses, advertising and sponsorship of budget users;

- The control of employment of temporary employment agencies, and control of eventual payment of these people engaged in public institutions, etc.;

- Immediate termination of giving bonuses and reducing other costs of public enterprises;

- Reduction of capital expenditure and public enterprises;

- Part of government capital expenditure projects will be protracted and would take the new dynamics of implementation and payment.

Credit supports of economic subjects-companies represent the second segment of the third package, which directly supported the real sector of the credit lines of the European Investment Bank. Credit lines for support of small and medium sized enterprises reached the amount of 100 million Euros. The government provided additional funding sources from the commercial banking sector worth 50-100 million Euros. In order to use these credit lines, small and medium enterprises had to meet the basic requirement: maintaining staff numbers and the orientation towards exports. Funds received from credit lines could be used to support $50 \%$ of exports and $50 \%$ in the reprogramming of loans taken.

Credit support package contains four programs of economic subjects, including:

- Co-financial long term loans for investment in the value of $50 \%$ and the full guarantee of the share of co financed and interest rate subsidies;

- Co-financing of short-term loans for cash flow value of $50 \%$ and guarantee of a full co financial part of, and interest rate subsidies;

- Subvention of interest loans approved by commercial banks;

- Guarantee program.

The co-financing of long-term investment programme loans guaranteed a complete co financial part, and of interest subsidy was accomplished through the Macedonian Bank for Development Support (MBDS) worth 70 million Euros (35 million euro from EIB and 35 million Euros from commercial banks in the country).

Key Components and the maximum loan term are predicted to be: up to 20.000 Euros for micro firms; up to 150.000 Euros for small firms and up to 500.000 Euros for medium firms, with these condition: payment term 5 years old and 12 months grace period and interest rates in ProCredit maximum 3-month Euribor $+4 \%$ annually (higher rate 6\%).

According to the program for co-financing and guarantee loans for cash flow and anticipated interest rate subsidy to be allocated funds in the amount of 90 million Euros (45 million euro from EIB and 45 million Euros from commercial banks) in the country. Major components and the maximum value of short-term loans are provided: up to 10.000 Euros for micro firms; up to 70.000 Euros for small firms and up to 200.000 Euros for medium firms with these condition: payment term: 12 months and interest rates in maximum 3-month Euribor $+4 \%$ annually (higher rate $6 \%$ ).

The programme for subsidizing the interest on shortterm loans for cash flow provides for a value of 15 million. Through the MBDS 5\% will be subsidized by the general interest provided that the remaining portion that the loaner of commercial bank will pay is not higher than Euribor $3 m+4 \%$ annually (maximum 6\% per year). Key Components and the maximum term loans are determined as follows: up to 10.000 Euros for micro firms; up to 70.000 Euros for micro firms; up to 200.000 Euros for micro firms; with these condition: payment term: 12 months.

The programs for guarantees provided by MBDS would include guarantees for entities that would implement the contractual obligations, as well as those that will appear in foreign markets and other types of guarantees. These programs occupy a value of 15 million.

Other measures to support economic entities that have been brought by the government:

- 54-measures to simplify procedures and customs operations in order to quickly move goods at the borders. All this is stipulated in the second stage regulator of Gilotina.

- 10 harmonized measures with the interests of rooms in the country.

- Some concrete measures in support of carriers in the transport sector in coordination with unions Makamtrans (Agency of the transport trade unions in Macedonia).

\subsection{The fourth package of anti-crisis measures}

The Government of the Republic of Macedonia in March 2010 unveiled the fourth package of anti-crisis measures. This package itself includes 23 different types of measures dedicated sectors, procedures, different laws, etc., in more detail following anti-crisis measures will be presented to the fourth package. 


\section{Measure-1:}

- Changing the conditions for using credit lines from the EIB and MBDS. Limitation of interest rates during the first $6 \%$, limitation of the maximum interest rate for the second year to $7,5 \%$

- Change in value of individual loans to final destination (micro trade to 40.000 Euros to 400.000 small commercial euro 3.500.000 euro commercial medium)

- Expand of possibilities with what commercial companies will have access to compete for division of these loans.

Measure-2:

- Changes and fulfilling of the VAT law,

- The possibility of electronic tracking of periodic financial reports bank accounts to the Revenue Department Public,

- Separation of the day payment of obligations to the gross salary and contributions to the obligation to VAT from 15 up on 25 next month,

- Raising the threshold of registration in the VAT from 1.3 million to 2.0 million denars.

Measure-3: Fulfilling and changing the Law on Housing, which will enable the purchase of state-owned apartments by the holder of the right of residence and who have owed for not paying rent. The debt will be calculated on the price of the apartment and will be paid by the date specified in the contract.

Measure-4: Facilitating the criteria for receiving financial support in accordance Program for financial support to agriculture in 2010

Measure-5: Fulfilling and changing the Law on Spatial and Urban Planning, OG nr.91/2009, namely section, 17, added that the law applies to the initiatives set for commercial buildings with character.

Measure-6: The harmonization of the Law on Construction Land and Building Law in respect of deadlines for construction in order to delay the deadline for obtaining approval for the construction of a building of category 1 and 2 in 10 years, category 3 to 6-years and category 4 - 5 in 4-years.

Measure-7: Fulfilling and changing the Law on spatial planning and urban in terms of prolongation of the deadline for obtaining approval for construction from one to two years.

Measure-8: Reduction of compensation for the privatization of construction land for $30 \%$ of legal persons.

Measure-9: Implementation of credit line for firms (micro, small and medium) with the guarantee scheme by MBDS the total 15 million Euros.

Measure-10: The harmonization of procedures for making grants under the Programme for financial support for rural development and IPARD program with procedures for obtaining loans in commercial banks in order to create equal access in the preparation of business plans and documentation, which will be needed for both cases.

Measure-11: Prohibition of import of products produced without the standard HACCAP, CE) in order to protect domestic producers and consumers.
Measure-12: Reduction of compensation for the use of financial services brief statement from the annual account, the Central Registry of the annual accounts on an annual lump sum of 8000 denars, with unlimited access to 500 monthly information to companies who use this service.

Measure-13: Bringing the law establishing the Agency for Foreign Investment in RM and export promotion.

Measure-14: Building more accessories to travellers in the corridor of 8 and 10 and note of Markel building commercial buildings, with which will be a transit enables travellers to contribute to the development of national economy.

Measure-15: Creating a manual, which in detail will be described the procedures for obtaining DUP (Detailed Urban Plan) and procedures for granting building permits, along with documentation, and establishing communication between the institutions that must share consent (opinion) adequate.

Measure-16: Changes in the Building Law in terms of reducing the procedures: not given permission for use of facilities, but the report from the technical review committee to be final.

Measure-17: Changing the Law on transport of passengers in road traffic, which will reduce the volume of administrative procedures, with which Ministry of Transport and Communications will use data from system EXIM.

Measure-18: Reduction of procedures for processing the GUP (General Urban Plan) the rule which will be a need for Surveying-date basis in the preparation of the Urban Plan.

Measure-19: Setting administrative access control data necessary for applying for the financial aid by using the support program to reduce application costs.

Measure-20: Establishment of a fund for the rehabilitation of agricultural land with the aim of providing unemployed individuals residing in rural areas. Measures will be implemented under the Law on agricultural land and grant program for agricultural land in state ownership for revitalization.

Measure-21: Part of the mechanisms which supplies agricultural Ministry of Agriculture Forestry and Water Revolving Funds of funds donated by the Japanese Government for the supply of agricultural equipment, to be allocated to individuals, which will be given revitilazed land by Measure 20 .

Measure-22: Amendments to the Law of Economic Chamber, which will be possible with equal treatment for the all customs matters of economic chambers registered in the RM.

Measure-23: Amendments to the Law on denationalization, or reduction procedures, which, in addition to other legal proceedings, will make a ruling on the viability of the second instance commission for denationalization.

\section{THE EFFECTS OF THE ANTI CRISIS MEASURES AND} REDUCING THE NEGATIVE EFFECTS OF THE FINANCIAL CRISIS IN THE BUSINESS SECTOR

The economy of the region represents a complex collection of all economic activities, local and national policies, including a number of factors determining it. The national 
economy represents quite complex symbiosis of all local or regional economies of the country. Constant functioning of branches of economic activities in general represents a necessary condition to sustainable development of a regional or national economy. The negative impact of internal and external factors has managed to shift the economies of the different set of economic stability many times. The last case was the global financial crisis, which, with its negative impact, shocked the global economy, causing them the most severe recessions of recent years.

Considering that this crisis has been very tough and ruthless to all economies, without choosing the size or extent of their economic development, we decided to implement this research to evaluate the negative effects that this crisis has caused to the business sector in the Pollog region.

The Pollog region is known as a region of private initiatives and the executor of many successful businesses. These businesses have realized high profits for the owners of these businesses, but the global financial crisis, significantly, has led in this direction.

\section{Sample description}

The survey sample includes $288 \mathrm{Small}$ and medium sized enterprises from the Pollog region. As can be noticed from the data presented in table 2, the sample includes SME's of different characteristics when it comes to the industrial branch they are active in, date and reasons of creations, level of economic activity etc.

Chart 1: Sample description by activity and period of foundation
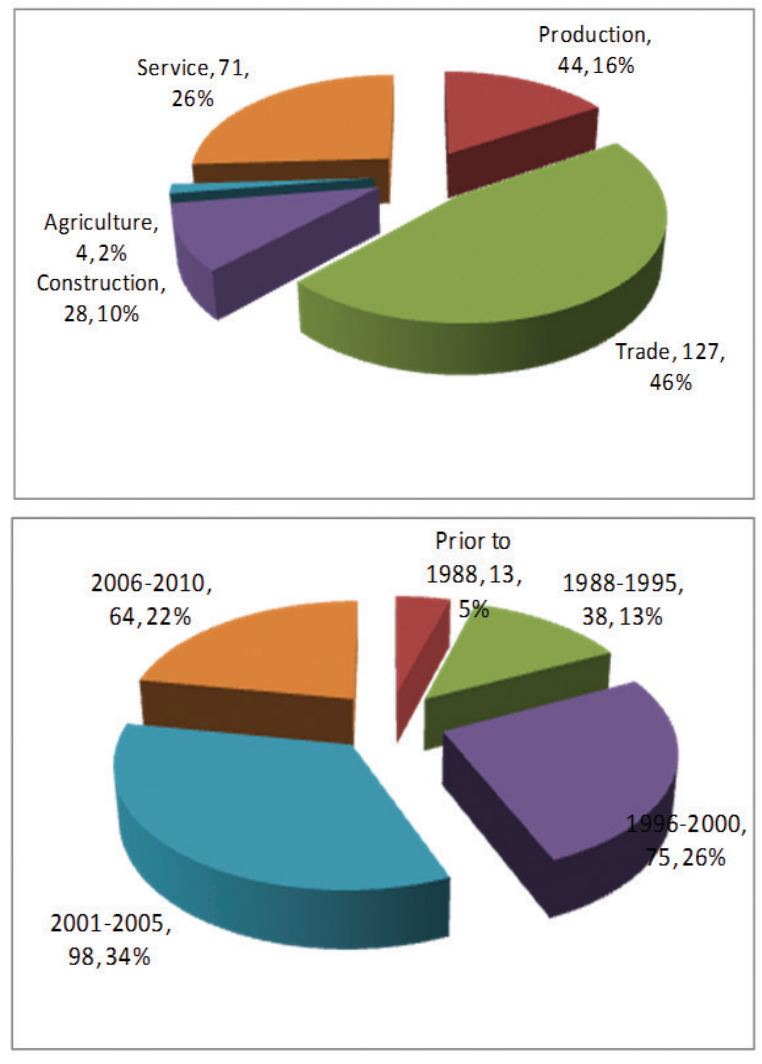

As can be seen from table 2 the sample is dominated by companies that deal with trade. Besides this most analysed companies are founded in the period 1996-2005.

The global economic crisis, though not in the same measure, has affected all the small and medium businesses in the Pollog region. This is proved by the fact that $12 \%$ of owners of small and medium businesses stated that their company's activity is not reduced at all during the global economic crisis. Over $1 / 3$ of companies have declined to $10 \%$ of their activity during the global economic crisis and only $15 \%$ have decreased their activity over $26 \%$. The rest of the businesses surveyed have decreased activity between 10\%-25\% during the global economic crisis, (see chart 1).

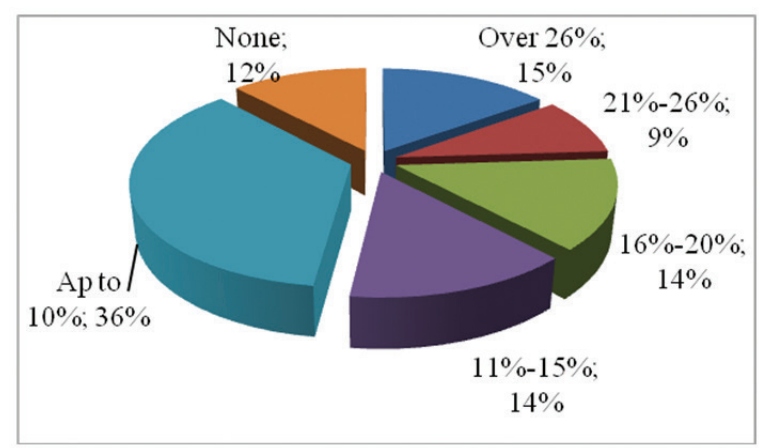

The research showed a very high degree of dissatisfaction among owners of small and medium businesses in the Pollog region, with the support for dealing with economic crisis provided by the central government through the anti-crisis measures, (see table 1).

\begin{tabular}{|c|c|c|}
\hline \multicolumn{3}{|c|}{ Table 1: Satisfaction of businesses with government } \\
anti-crisis steps \\
\hline Answer & $\mathbf{n}$ & $\%$ \\
\hline None & 183 & 63,763 \\
\hline Little & 56 & 19,512 \\
\hline In a way & 38 & 13,24 \\
\hline Satisfied & 9 & 3,1359 \\
\hline Very satisfied & 1 & 0,3484 \\
\hline $\begin{array}{c}\text { Source: Authors calculations-The questionnaire was con- } \\
\text { ducted in 288 SME's in Pollog Region }\end{array}$ \\
\hline
\end{tabular}

Tax reform, i.e. non-payment of tax on profit for the year 2010, as a step towards lessening the negative effects of global economic crisis, it has provided not nearly the expected effects on the region Pollog. This is confirmed by the fact that over $24 \%$ of entrepreneurs have declared that this measure has not softened at all the negative effects of the economic crisis, while close to $40 \%$ of the respondents stated that this measure has helped alleviate some negative effects of global economic crisis. In addition, a quarter of respondents consider that the waiving of tax on profit for the year 2010 has been some help in alleviating the consequences of the crisis. Only $7 \%$ of the respondents stated that this measure has helped their company in dealing with global economic crisis, (see chart 2). 
Chart 3: Impact of non-payment of tax on profit for the year 2010 to alleviate the negative effects of global economic crisis in the region of Pollog

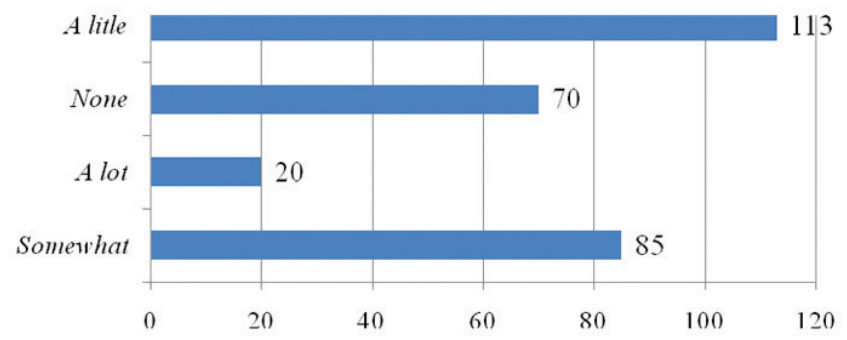

The government of Macedonia, up to March 2010, has approved four anti-crisis packages of measures which have been a very broad spectrum.

The most significant impact of anti-crisis measures is seen in the established firms in the period until 1988 in comparison with other firm's analyzed periods. From surveyed companies in this period, 53, 85\% declared that these measures have had little impact or have been to some extent influential $123.08 \%$ and $30.77 \%$ ) while $46.15 \%$ stated that these measures have not been impact on their businesses, (Table 2).

\begin{tabular}{|c|c|c|c|c|c|}
\hline \multicolumn{6}{|c|}{ Table 2: The influence of anti-crisis measures in business (\%) } \\
\hline $\begin{array}{c}\text { Seniority of } \\
\text { business }\end{array}$ & Not at all & Little & $\begin{array}{c}\text { To some } \\
\text { point }\end{array}$ & $\begin{array}{c}\text { Satis- } \\
\text { fied }\end{array}$ & A lot \\
\hline $\mathbf{- 1 9 8 8}$ & 46,15 & 23,08 & 30,77 & 0,00 & 0,00 \\
\hline $\mathbf{1 9 8 9 - 1 9 9 5}$ & 57,89 & 21,05 & 18,42 & 2,63 & 0,00 \\
\hline $\mathbf{1 9 9 6 - 2 0 0 0}$ & 55,41 & 25,68 & 13,51 & 5,41 & 0,00 \\
\hline $\mathbf{2 0 0 1 - 2 0 0 6}$ & 68,69 & 13,13 & 14,14 & 4,04 & 0,00 \\
\hline $\mathbf{2 0 0 6 - 2 0 1 0}$ & 71,88 & 20,31 & 4,69 & 3,13 & 0,00 \\
\hline
\end{tabular}

Source: Authors calculations-The questionnaire was conducted in 288 SME's in Pollog Region

As can be noticed from the data presented in chart 4 all industries have noticed the negative effects of the global financial crisis when it comes to the level of investments. The highest decrease is among agricultural and trade companies as well as companies that have been founded in the period 2006-2010.

Chart 4: The global financial crisis and investments in the Pollog region

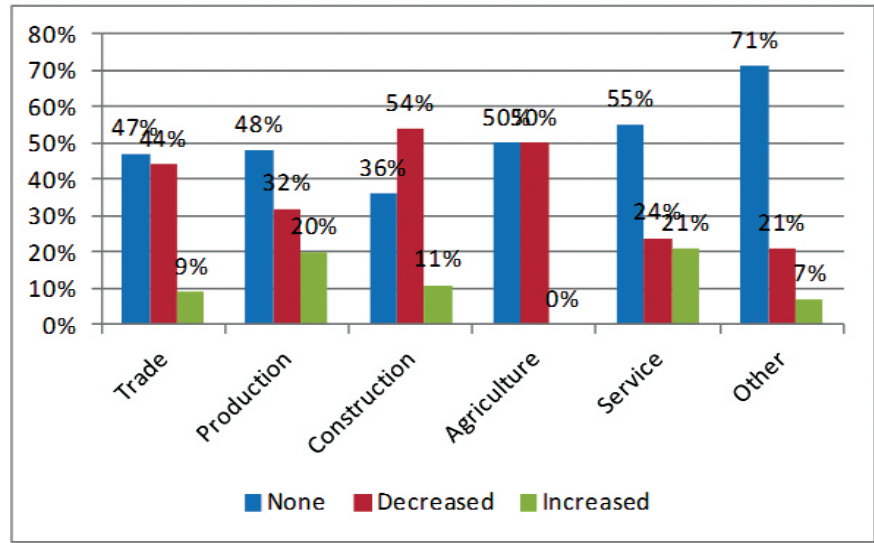

Non impact of anti-crisis measures become most significant in most of the firms established closer to the global financial crisis $(55.41 \%-71.88 \%)$, but within these periods is presented a smaller number of firms $(2.63 \%-5.41 \%)$ that are satisfied by the anti-crisis measures.

From the correlation of seniority of business and the possibility of turning positive in 2010 following findings emerge, (see Table 3).

Table 3: Will 2010 mark a positive turnaround?

\begin{tabular}{|c|c|c|c|c|}
\hline $\begin{array}{c}\text { Seniority of } \\
\text { business }\end{array}$ & $\begin{array}{c}\text { Not at } \\
\text { all }\end{array}$ & Little & $\begin{array}{c}\text { To some } \\
\text { point }\end{array}$ & A lot \\
\hline $\mathbf{- 1 9 8 8}$ & $7,69 \%$ & $30,77 \%$ & $46,15 \%$ & $15,38 \%$ \\
\hline $\mathbf{1 9 8 9 - 1 9 9 5}$ & $15,79 \%$ & $21,05 \%$ & $50,00 \%$ & $13,16 \%$ \\
\hline $\mathbf{1 9 9 6 - 2 0 0 0}$ & $14,67 \%$ & $14,67 \%$ & $58,67 \%$ & $12,00 \%$ \\
\hline $\mathbf{2 0 0 1 - 2 0 0 6}$ & $23,47 \%$ & $28,57 \%$ & $40,82 \%$ & $7,14 \%$ \\
\hline $\mathbf{2 0 0 6 - 2 0 1 0}$ & $20,31 \%$ & $15,63 \%$ & $53,13 \%$ & $10,94 \%$ \\
\hline
\end{tabular}

Source: Authors calculations-The questionnaire was conducted in 288 SME's in Pollog Region

The most significant belief in the positive turnaround of the year 2010 is seen in the older tradition businesses. About $15,38 \%$ of the respondents from the period 1988 declare that a positive turnaround is going to happen in $2010,76,92 \%$ belive in a small turnaround, to some extend $(30,77 \%$ and $46,15 \%)$, while only $7,69 \%$ don't believe in a situation improvement.

Firms state of the period 1989-1995 is the following one: about $13.16 \%$ that 2010 will have more positive twist, while $71.50 \%$ believe there will be little and to some extent $(21.05 \%$ and $50.00 \%$ ), while $15.79 \%$ do not believe that will have improvement of the situation.

Analyses made for the period 1996-2000 show that about $12.00 \%$ of firms believe that the 2010 will turn more positive, while $73.33 \%$ believe there will be little improvement and to some extent ( $14,67 \%$ and $58.66 \%$ ), while $14.67 \%$ do not believe that will have improvement of the situation.

About 23.47 of the firms show pessimism in the improvement of the situation in the period of 2001-2005, while $69.39 \%$ are optimistic and to some extent that little improvements will be made ( $28.57 \%$ and $40.82 \%)$; while $7.14 \%$ think there will be many improvements in their businesses.

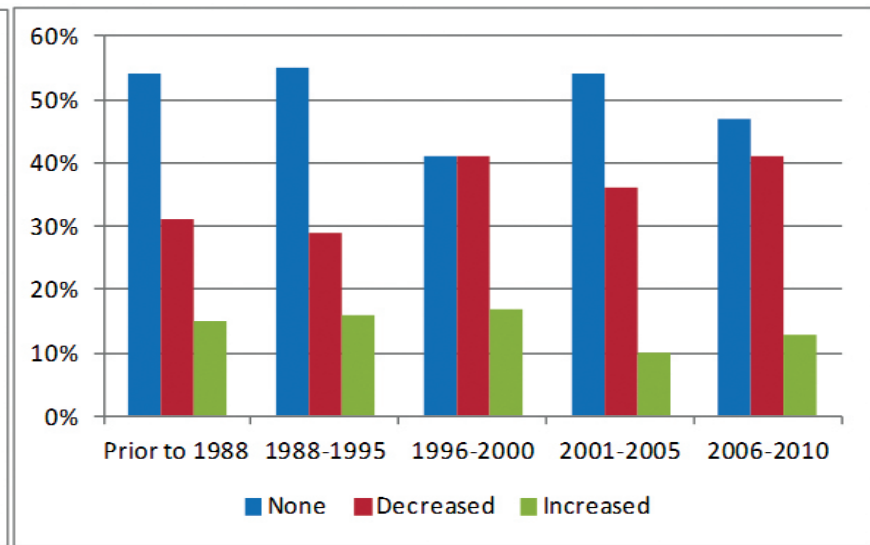


According to analysis made for the period 2006-2010 we can conclude that about $10.94 \%$ of firms of this period believe that 2010 will turn more positive while the $68.75 \%$ believe there will be few and to some extent (15.63\% and $53.13 \%)$, and $20.31 \%$ do not believe that will have improvement of the situation.

\section{CONCLUSION AND RECOMMENDATION}

The economy of Macedonia, in 2009, highlighted the effects of the global financial crisis. Perhaps the first effects were felt in the last quarter of 2008- but with more evident consequences in 2009. In order to prevent and alleviate the negative consequences from the global financial crisis, the government of the RM has implemented four anti-crisis measures.

The research showed a very high degree of dissatisfaction among owners of small and medium businesses in the
Pollog region, with the support for dealing with economic crisis provided by the central government through the anti-crisis measures.

Older companies proved to be more resistant to the negative effects of the global financial crisis.

The impact of anti-crisis measures was not balanced in all regions of the Republic of Macedonia. The consequences of the global financial crisis in Polog are very evident.

The general impression of the more of surveyed SME's in Pollog region is that the impact of packet of anti crisis measures undertaken by government of RM was very pal.

Our opinion is that the government should take an active policy aimed at the real revival of the proposed anti-crisis measures. In other hand the government must be cooperative with the local government in order to improve the business climate for the business sector.

\section{REFERENCES:}

1. Berkmen, P. Gelos, G., Rennhack, R. and Walsh, J.P., 1999. The Global Financial Crisis: Explaining Cross-Country Differences in the Output Impact. Washington: International Monetary Fund.

2. Brumer, R.F., Charled, A. and Bott, Ch, A., 2009. The Dynamics of a Financial Dislocation: The Pani cof 2007 and the Subprime Crisis, Insights into the Global Financial Crisis. Virginia: CFA Institute Publishing.

3. Government of R. Macedonia, 2009. Cabinet of Vice premier, Third packet ant crisis measures, [online] Available at: <http://www.vicepremier.gov.mk/?q=node/451>, [Accessed 05 October 2011].

4. Muchau, W., 2010. The Meltdown Years: The Unfolding of the Global Economic Crisis. New York: McGraw/Hill Publishing.

5. Mazllami, J., Zeqiri, Z. and Aziri, B., 2011. The Impact of the Global Financial Crisis on the Macedonian Economy: An Analysis of the Pollog Region. Saarbrucken: LAP Lambert Academic Publishing GmbH \& Co. KG.

6. Turner, G., 2008. The Credit Crunch Housing Bubbles, Globalization and the Worldwide Economic Crisis. London: Pluto Press,.

7. World Trade Organization, 2009. World Trade Report 2009 (pdf): Trade Policy Commitments and Contingency Measures: How Can Trade Remain Open in Time of Crisis? Available at: [Accessed 05 October 2011].

8. <http://www.wto.org/english/res_e/reser_e/wtr09_brochure_e.pdf> 


\section{MANAGING OF THE 2008 FINANCIAL CRISIS BY THE GOVERNMENT OF THE REPUBLIC OF MACEDONIA AND ITS IMPACT ON THE BUSINESS SECTOR}

\section{JETON MAZLLAMI}

https://doi.org/10.35945/gb.2017.03.006

Assistant professor of SEEU Tetovo, Macedonia

IZET ZEQIRI

Full professor of SEEU Tetovo, Macedonia

BRIKEND AZIRI

Associate professor of STU Tetovo, Macedonia

KEYWORDS: ANTI CRISIS MEASURES, SME'S, INVESTMENTS, EMPLOYMENT ACT

\section{SUMMARY}

The economy of the R.M. did not have the necessary immunity to face the worldwide consequences of the global financial crisis that hit most of the western national economies a few years ago. In order to prevent and alleviate the negative consequences, the government of the RM during the period from 2008 to 2010 has taken some anticrisis package of measures. The government has introduced four packages of anti-crisis measures in the period 2008-2010. The aim of this paper is to analyze how the government of the Republic of Macedonia facing with the 2008 financial crisis, how the government was implement the anti crisis measures and finally what is the impact of financial crisis in the business sector with special emphasize the Pollog region. A large scale survey in SME's has been conducted in order to get a clearer picture from the business point of view. 